\title{
NUMERICAL MODELLING OF HYDRODYNAMICS AND SEDIMENT TRANSPORT PROCESSES DURING STORM EVENTS IN A NON-PERENNIAL RIVER
}

\author{
RAAJ RAMSANKARAN ${ }^{1)}$, CHRISTIAN MAERKER ${ }^{2)}$, ANDREAS MALCHEREK ${ }^{2)}$ \\ ${ }^{1)}$ Department of Civil Engineering, Indian Institute of Technology Roorkee, Roorkee 247 667, Uttarakhand, India; Visiting scholar \\ during 1. 10. 07-30. 9. 08 at Institute of Hydro Sciences, German Federal Armed Forces University Munich, Werner-Heisenberg- \\ Weg 39, Neubiberg 85577, Munich, Germany. Corresponding author; Mailto: ramsankaran_raaj@yahoo.co.in \\ ${ }^{2)}$ Institute of Hydro Sciences, University of the German Armed Forces Munich, Werner-Heisenberg-Weg 39, Neubiberg 85577, \\ Munich, Germany.
}

This article presents the numerical modelling of hydrodynamics and sediment transport processes in the seasonal Pathri Rao River, which flows in the Northern part of India. Modelling is made by the coupled application of the hydrodynamic model called TELEMAC-2D and the morphodynamic model called SediMorph. The hydrodynamic model results are validated with the observed data and it has been found that the present model provides reasonable predictions. Likewise, the validation of the morphodynamic model is also presented. For this purpose, the suspended and bed load transport modules are validated separately for four runoff events observed during the investigations. The validation of the former is approached by comparing the depth-averaged suspended transport concentrations against experimental measurements made at the make-shift gauging station and subsequent comparison against experimental measurements. On the other hand, due to non-availability of the observed values on bed load sediment transport, the bed load sediment transport and bed evolution numerical results could not be validated quantitatively and was approached only on qualitative basis. In general, both validations present an acceptable agreement with measurements and scientific facts. Further, this study demonstrates that the coupled TELEMAC-2D/SediMorph system could be used with confidence for practical applications in the Pathri Rao River.

KEY WORDS: Runoff Event Modelling, SediMorph, Sediment Transport, TELEMAC-2D.

Raaj Ramsankaran, Christian Maerker, Andreas Malcherek: NUMERICKÉ MODELOVANIE HYDRODYNAMICKÝCH JAVOV A TRANSPORTU SEDIMENTOV POČAS PRÍVALOVÝCH ZRÁŽOK V OBČASNÝCH TOKOCH. J. Hydrol. Hydromech., 58, 2010, 1; 14 lit., 8 obr., 3 tab.

Príspevok obsahuje výsledky numerického modelovania hydrodynamických javov a transportu sedimentov v občasnom toku Pathri Rao, v severnej časti Indie. Procesy boli modelované zdvojenou aplikáciou hydrodynamického modelu TELEMAC-2D a morfodynamického modelu SediMorph. Výsledky modelovania hydrodynamickým modelom boli verifikované s využitím pozorovaných hodnôt; bolo zistené, že model dáva akceptovatel’né výsledky. Prezentuje sa tiež verifikácia morfodynamického modelu. Počas epizód odtoku bol transport suspendovaných častíc a častíc transportovaných po dne toku verifikovaný osobitne. Verifikácia transportu suspendovaných častíc bola uskutočnená porovnaním hĺbkovo spriemerovanými koncentráciami suspendovaných častíc s meranými hodnotami na prietokomerných staniciach. Pre nedostatok pozorovaných údajov o dnovom transporte, údaje o ňom a o zmenách morfológie toku mohli byt' verifikované len kvalitatívne. Záverom, obe verifikácie dali akceptovatel'nú zhodu s výsledkami meraní a existujúcimi vedeckými poznatkami. Okrem toho výsledky štúdie demonštrujú schopnost' zdvojených modelov TELEMAC-2D/SediMorph získavat' spol'ahlivé výsledky pri aplikácii na rieke Pathri Rao.

KLÚČOVÉ SLOVÁ: modelovanie odtoku, SediMorph, transport sedimentov, TELEMAC-2D.

\section{Introduction}

During flood, excessive loads of sediments are being transported by overland drainage and riverine flows to many lakes, reservoirs and estuaries which in turn reduces the capability of rivers and streams to carry flood water, reduces water storage in lakes and reservoirs, pollutes surface waters, and can 
cause or increase bank erosion. Subsequently, rivers may frequently adjust their cross-section, longitudinal profile, course of flow and pattern through sediment transport, erosion and deposition. In order to sustain cultural and economic developments along a river basin, it is essential to understand the principles of sediment transport for application to the solution of engineering and environmental problems associated with natural events and human activities. Gaining such knowledge in spatial, temporal and volumetric characteristics of the sediment being eroded, transported and deposited needs continuous exhaustive experiments, which will not be possible in all cases because of cost, time and manpower requirements.

Hence, management of river basins demands the need for numerical river simulation models to predict the water levels, flow velocities and sediment transport accurately during flood events. The rapid development of mathematical methodologies and the advances of computational facilities, sophisticated simulation tools using highly efficient and user-friendly computers have made this possible and become easily accessible to engineers and scientists. Moreover, such computational models have advantages over traditional physical models by being reusable, cost-effective, user-friendly with built-in pre- and post-processors and easily applicable to various proposed design scenarios.

However, to obtain the confidence on the applicability of such models in field applications, results of all those numerical models should be validated either quantitatively or qualitatively (if no field observations available). Hence, for this purpose the in-house model namely SediMorph, a sediment transport model being continuously developed at UniBw, Munich, was tested for its performance and the results are presented herein. Since SediMorph can be used in connection with different hydrodynamic models, it has been coupled with the TELEMAC-2D (Hervouet, Bates, 2000) hydrodynamicnumerical $(\mathrm{HN})$ model for this study. Then the coupled models were used to simulate the erosion, deposition and bed evolution process in the Pathri Rao River, a tributary of Ganga River which flows in Northern India.

\section{Description of the numerical models}

\subsection{SediMorph}

The mathematical model SediMorph is 3D (three-dimensional) FV (finite volume) based mor- phological and graded sediment transport model, which simulates the physical processes of the soil under surface waters. This state-of-the-art 3D morphodynamics numerical model was initially developed by the German Federal Waterways Institute (BAW), Hamburg, and it is being developed in cooperation with the Institute of Hydro sciences at German Federal Armed Forces University, Munich.

SediMorph is able to work on unstructured orthogonal grids (UOG). The modelling domain is covered by a grid consisting of a set of nonoverlapping convex polygons, usually either triangles or quadrilaterals. SediMorph is implemented in such a way that it can be coupled with different hydrodynamic models by well-defined user interfaces using language features of FORTRAN 90. During simulations, the hydrodynamic-numerical model passes the water height and the depth averaged velocity to SediMorph.

SediMorph works on a sediment classification defined by the user through a sediment classification file. SediMorph can handle five different sediment fractions. This file contains the specification of the sediment classes by defining their grain diameters and grain densities. This could be the Udden-Wentworth scale but any other classification is also possible. An example for the data stored in such a file is shown in Tab. 1. This sediment classification is used in this study.

$\mathrm{T}$ a b 1 e 1. Sediment classification used for the Pathri Rao River simulation.

$\mathrm{T}$ a b u l' k a 1. Klasifikácia sedimentov použitých pri simulácii v rieke Pathri Rao; 1 - trieda sedimentov, 2 - názov, 3 - reprezentatívny priemer, 4 - reprezentatívna hustota.

\begin{tabular}{|c|c|c|c|}
\hline $\begin{array}{l}\text { Sediment } \\
\text { class }^{1)}\end{array}$ & $\mathrm{Name}^{2)}$ & $\begin{array}{l}\text { Representative } \\
\text { diameter }^{3)} \\
{[\mathrm{mm}]}\end{array}$ & $\begin{array}{l}\text { Representative } \\
\text { density } \\
{\left[\mathrm{kg} \mathrm{m}^{-3}\right]}\end{array}$ \\
\hline 1 & Fine silt & 0.0078 & 2650 \\
\hline 2 & Medium sand & 0.375 & 2650 \\
\hline
\end{tabular}

In this way the data structure can take into account more sediment properties like for example, the Corey shape factor and the related transport processes very easily.

SediMorph is also able to take into account the water content or porosity of the sediment soil. This information is needed to estimate accurately the erosion properties. The soil porosity can either be calculated using the grain size distribution or being given by the model user. In this way, SediMorph can work on every kind of sediment classification. 


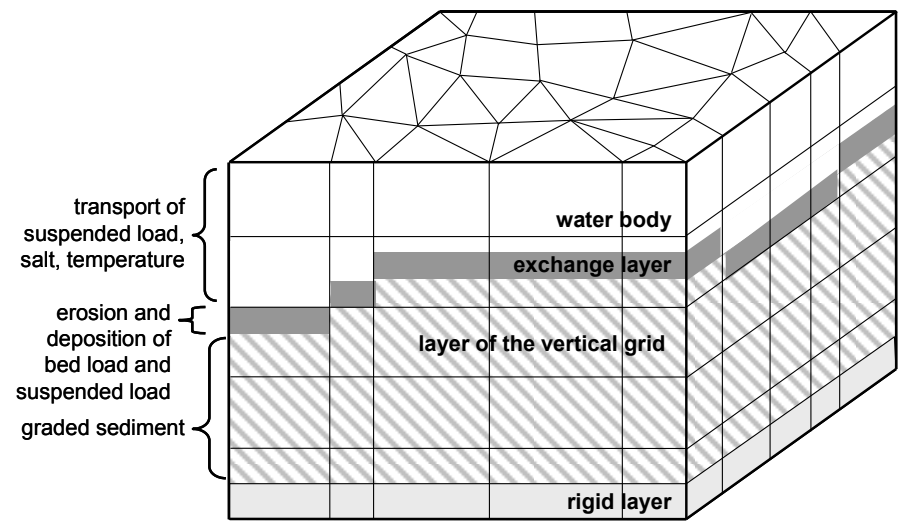

Fig. 1. Structure of the morphological dataset in SediMorph.

Obr. 1. Štruktúra morfologických údajov v SediMorph.

The morphological data set of the simulation can be constructed based on this sediment classification. It consists of a two-dimensional unstructured mesh with several vertical layers. In this way, a mesh of volume cells is defined (see Fig. 1).
For every cell of this 3D simulation mesh, initial conditions for the sediment distribution and the porosity must be specified as addressed in the Tab. 2.

T a b l e 2. Example of a morphological data set.

T a b u l'k a 2. Príklad súboru morfologických údajov koryta.

\begin{tabular}{lcccccc}
\hline Cell number & $\begin{array}{l}\text { Sediment } \\
\text { Class 1 }\end{array}$ & $\begin{array}{l}\text { Sediment } \\
\text { Class 2 }\end{array}$ & $\begin{array}{l}\text { Sediment } \\
\text { Class 3 }\end{array}$ & $\begin{array}{l}\text { Sediment } \\
\text { Class 4 }\end{array}$ & $\begin{array}{l}\text { Sediment } \\
\text { Class 5 }\end{array}$ & Porosity \\
\hline 1 & 0.7 & 0.3 & 0.0 & 0.0 & 0.0 & 0.3 \\
2 & 0.3 & 0.5 & 0.1 & 0.1 & 0.0 & 0.3 \\
3 & 0.0 & 0.4 & 0.5 & 0.0 & 0.1 & 0.4 \\
$\ldots$ & $\ldots$ & $\ldots$ & $\ldots$ & $\ldots$ & $\ldots$ & $\ldots$ \\
$n$th cell & 0.2 & 0.5 & 0.0 & 0.2 & 0.1 & 0.36 \\
\hline
\end{tabular}

The exchange layer (most upper layer of sediment) is defined and its depth can be specified by the user. This layer is in contact with the fluid and accomplishes the erosion and deposition of sediment during the simulation. The specific volume of the sediment classes' changes according to sediment transfer in the exchange layer, and the distribution gets finer or coarser. In case of emptying the exchange layer, it is filled up from the underlying cell. Thus, the change in sediment distribution is slower in underlying cells. This exchange layer concept is applied for the calculations of the initiation of sediment movement, the sediment transport and in the grain roughness.

Bed forms like ripples and dunes are taken in to account by their wave number vector and their height. It should be mentioned that the generation of ripples and dunes is not simulated by the model at this stage (Malcherek et al., 2005). Bed roughness is calculated depending on the grain size distribution in the exchange layer and bed forms pre- sent. The sediment transport rate is the result of mass conservation and momentum balance in the sediment layer at the bed. SediMorph does not take into account these processes but instead calculates the transport capacity from any of the empirical relations proposed by Meyer-Peter, Mueller (1949) or Engelund, Hansen (1967) or van Rijn (1984) or Zanke (1999), depending on the flow and exchange layer properties as selected by the user (Malcherek et al., 2005). SediMorph calculates the erosion flux of the suspended and bed load as well as the transport of bed load. As some formulation for the bed load transport requires a threshold shear stress to begin the sediment movement, it is calculated using the Shields critical shear stress criteria which has the following form

$$
\tau_{\mathrm{c}}=\theta_{\mathrm{c}}\left(\bar{\rho}_{\mathrm{s}}-\rho\right) \mathrm{g} d_{50} \quad \text { with } d_{50} \cong d_{\mathrm{m}},
$$

where $\tau_{\mathrm{c}}$ - critical shear stress, $\theta_{\mathrm{c}}-$ Shields parameter, $\bar{\rho}_{\mathrm{s}}-$ average density of the sediments, $\rho-$ 
water density and $d_{50}$ - median diameter of the particles of interest.

The erosion rates for suspended sediments are calculated according to Partheniades (1965), which varies according to the availability of sediment amount in the exchange layer and porosity.

$$
\Phi_{\text {ero }}=\left\{\begin{array}{cc}
M_{\text {res }}\left(\frac{\tau_{\mathrm{b}}}{\tau_{\mathrm{ce}}}-1\right), & \tau_{\mathrm{b}} \geq \tau_{\mathrm{ce}}, \\
0, & \tau_{\mathrm{b}}<\tau_{\mathrm{ce}}
\end{array}\right.
$$

where $\Phi_{\text {ero }}-$ erosion flux, $M_{\text {res }}-$ erosion rate, $\tau_{\mathrm{b}}-$ Bottom shear stress and $\tau_{\mathrm{ce}}-$ critical shear stress for erosion.

The deposition fluxes are calculated using Krone (1962). The concentration in the water body, erosion flux and deposition flux of suspended load is simulated by the HN-model, which then passes the information of deposition fluxes to SediMorph. A rigid layer with a specific roughness is also considered. Reaching this layer, sediment is no more mobilised regardless of the effective bed shear stress.

$$
\Phi_{\mathrm{dep}}=\left\{\begin{array}{cc}
W_{\mathrm{c}} c\left(1-\frac{\tau_{\mathrm{b}}}{\tau_{\mathrm{cd}}}\right), & \tau_{\mathrm{b}}<\tau_{\mathrm{cd}}, \\
0, & \tau_{\mathrm{b}} \geq \tau_{\mathrm{cd}}
\end{array}\right.
$$

where $\Phi_{\text {dep }}-$ deposition flux, $W_{\mathrm{c}}$ - settling velocity, $c$ - depth averaged sediment concentration, $\tau_{\mathrm{b}}-$ bottom shear stress and $\tau_{\mathrm{cd}}-$ critical shear stress for deposition.

Then the mass balance at the bottom due to suspended sediment and bed load is calculated for each fraction. The evolution of the bed as a result of the sediment transport process described above is modelled by solving the following equation (also known as sediment continuity equation):

$$
(1-n) \frac{\partial z_{B}}{\partial t}+\operatorname{div} \overrightarrow{q_{S}}=\frac{\Phi_{\mathrm{S}}}{\rho_{\mathrm{S}}},
$$

where $n$ - porosity of the upper layer sediments, $z_{\mathrm{B}}-$ vertical coordinate of the upper layer of sediments, $\overrightarrow{q_{s}}-$ bed load sediment transport rate, $\rho_{\mathrm{s}}-$ dry sediment density and $\Phi_{\mathrm{S}}$ - sediment flux between the water column and the bed. It consists of the sum of erosion and deposition flux given as $\Phi_{\mathrm{S}}=\Phi_{\text {ero }}+\Phi_{\text {dep }}$.

Detailed information on the whole algorithm as well as implementation details can be found in the technical report by Malcherek et al. (2005).

\subsection{TELEMAC-2D}

TELEMAC-2D (Galland et al., 1991) is a twodimensional finite element model designed for the large range of studies in the domain of river and maritime hydraulics. It solves the non-conservative form of the shallow water (also known as SaintVenant or depth averaged) equations, which are simplifications of the full three-dimensional $\mathrm{Na}$ vier-Stokes equations. These equations are given in non-conservative form as

$$
\begin{aligned}
& \frac{\partial h}{\partial t}=\vec{u} \cdot \vec{\nabla}(h)+h \operatorname{div}(\vec{u})=0, \\
& \frac{\partial u}{\partial t}=\vec{u} \cdot \vec{\nabla}(u)+\mathrm{g} \frac{\partial h}{\partial x}-\frac{1}{h} \operatorname{div}\left(v_{\mathrm{t}} h \vec{\nabla}(u)\right)= \\
& =S_{x}-\mathrm{g} \frac{\partial z_{b}}{\partial x}, \\
& \frac{\partial v}{\partial t}=\vec{u} \cdot \vec{\nabla}(v)+\mathrm{g} \frac{\partial h}{\partial y}-\frac{1}{h} \operatorname{div}\left(v_{\mathrm{t}} h \vec{\nabla}(v)\right)= \\
& =S_{y}-\mathrm{g} \frac{\partial z_{b}}{\partial y},
\end{aligned}
$$

where $u$ and $v$ are the velocity components in the $x$ and $y$ Cartesian directions, $h$ - the depth of flow, $z_{\mathrm{b}}$ - the bed elevation, $v_{\mathrm{t}}-$ the turbulent viscosity, $S_{x}$ and $S_{y}$ - the source terms, $\mathrm{g}$ - the gravitational acceleration and $t$ is the time.

The model uses Galerkin's method of weighted residuals to solve Eqs. (5)-(7) over an unstructured mesh of triangular finite elements. A streamlineupwind-Petrov-Galerkin (SUPG) technique is used for the advection of flow depth in the continuity equation and the method of characteristics is used for the advection of velocity. The resulting linear system is solved using a gradient mean residual technique and efficient matrix assembly is ensured using element-by-element methods. The time development of the solutions is dealt with using an implicit finite difference scheme. Turbulence is treated by Reynolds averaging of the governing equations, with the Reynolds stresses calculated using the Boussinesq approximation. Friction is represented through a standard quadratic power law and drag coefficients given by Chezy, Manningstrickler or Nikuradse.

\section{Study site}

A 5-km long stretch (Fig. 2) of the Pathri Rao River flowing in the state of Uttarakhand, India, 
between the inlet near the Rajaji national park and the make-shift gauging point near the Upper Ganga canal aqueduct was considered.

The Pathri Rao River is a tributary of the Ganges River. The Pathri Rao River is a seasonal river, which flows only during North East monsoon period starting from mid June to mid September. The slope of riverbed is mild as shown in the Digital Elevation Model (DEM) (Fig. 3) of the river. It also shows the bed level elevation difference between upstream inlet and downstream outlet is about $40 \mathrm{~m}$ only. The geomorphic feature of the river does not vary much along the length of the study reach. The hydrograph and the sediment load data for this reach of the river were made available from the hydrological analysis and the field observations made by the first author. Those details on hydrological analysis and field observations are briefly outlined in the subsequent sections.

\section{Simulation methodology}

\subsection{Hydrological analysis}

To establish the quantity of flux entering the stream, a GIS-based hydrological modelling was performed over the upstream catchment area of the river. The area of the upstream catchment of the river is about $25 \mathrm{~km}^{2}$. For this purpose, the method adopted by Ramsankaran et al. (2009) for the same study area was implemented here. Here the modelling was done in a semi-distributed manner based on sub-basin discretization designed to capture actual landscape characteristics. The modelling begins by subtracting an empirically based initial loss caused by the interception of rainfall by vegetation before infiltration is calculated. Next, the Green-Ampt Infiltration hypothesis is adopted for the computation of runoff volumes which are then transformed into direct runoff using the unit hydrograph concept developed by the Soil Conservation Service (SCS). The transformed direct runoff is then routed towards the catchment outlet using the Kinematic Wave Model for channel flows. Several short duration storm events that occurred on 30th July, 14th August, 26th August and 12th September in the year 2006 were identified and simulated based on the above-mentioned hypothesis. The corresponding obtained surface runoff hydrographs were then taken as the inflows to the river for further modelling.

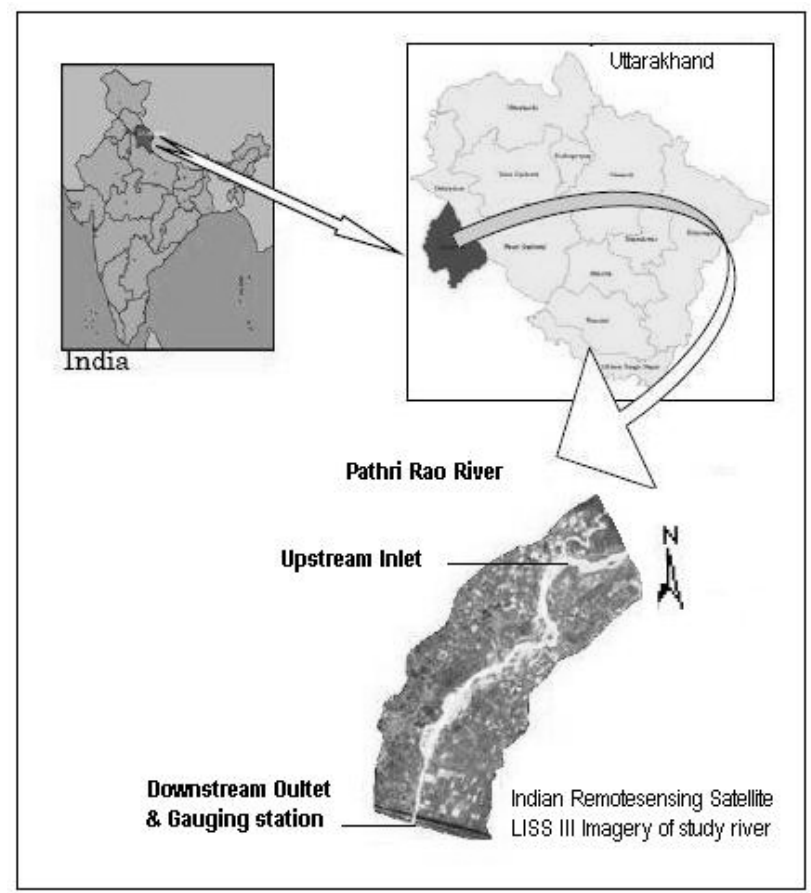

Fig. 2. Geographical location of the Pathri Rao River reach. Obr. 2. Geolografická charakteristika povodia Pathri Rao.

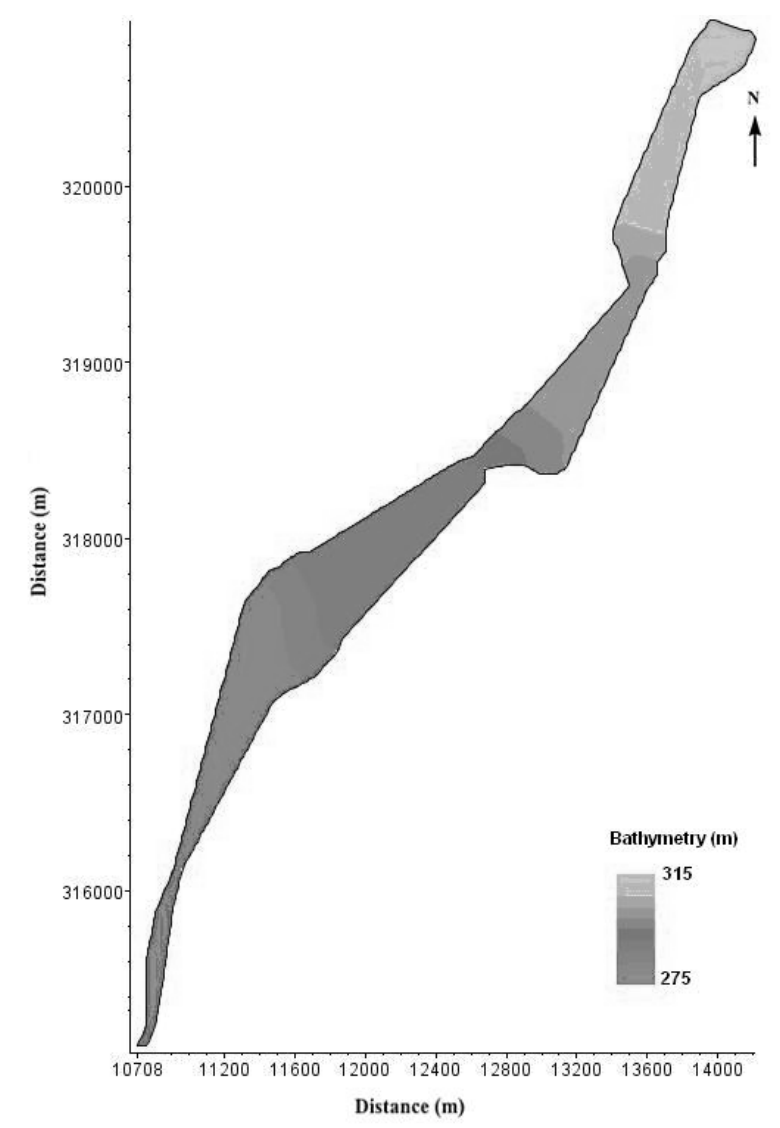

Fig. 3. Digital Elevation Model (DEM) of the Pathri Rao River reach.

Obr. 3. Digitálny model výšok povodia Pathri Rao. 


\subsection{In-situ measurements}

The river was gauged at its outlet for the present study for making observations on surface runoff discharge and sediment transport load. The gauging site was installed with a manually operated stage recorder to measure the depth of flow. Using that non-recording gauge, flow stages were manually recorded at 15 min time interval and average flow velocities were also measured simultaneously using a digital current meter. Based on these, corresponding discharge hydrographs were developed and utilised for the purpose of validation of the simulations reported herein.

Similarly the quantity of sediments carried by the flows were monitored at the gauging site by manually collecting the sediment-water mixture samples using cylindrical bottle sediment samplers at every $1 \mathrm{~h}$ interval. The concentration of sediment for each collected sample was determined by subsequently filtering, drying and weighing the collected samples in the laboratory. The sediment production rate from each storm runoff event was determined by using such measurements.

\subsection{Soil texture analysis}

The information on soil texture existing over the computational domain was obtained through field surveys by analyzing soil samples collected at different geo-referenced locations spread along the river bed. To accomplish this, particles greater than $2 \mathrm{~mm}$ in diameter are removed from the collected soil samples by sieving and are excluded from the soil textural determination. Soils are then classified into different textural classes based on the percentage of sand, silt, and clay. Determination of a soil's textural class names was best achieved using a USDA soil textural triangle and the same has been used in this study. Based on this it is found that the riverbed comprises of fine silt and medium sand sediment fractions of about $70 \%$ and $30 \%$ each, respectively.

\subsection{Modelling}

Based on the $10-\mathrm{m}$ contour intervals obtained from the Survey of India's digital toposheet of the study river, a DEM of size $(50 \times 50 \mathrm{~m})$ was created using the contour interpolation algorithms available in Arc-GIS ${ }^{\mathrm{TM}} 9.1$ package. Then those elevation points were used to create the unstructured (TINS) triangular irregular networks based on the Delaunay criteria (Peucker et al., 1978). The computational mesh formed (Fig. 4) thus consists of 3933 nodes with 7278 mesh elements. The runoff events that occurred on 30th July, 14th August, 26th August and 12th September in the year 2006 were considered for the simulations reported herein. For representing the flow conditions existing at the boundary nodes during the above-mentioned events, upstream inlet nodes were characterised as open boundary with prescribed flow rates, the side walls being characterised as impermeable solid boundaries and the downstream outlet nodes represented as open boundary with free velocities. The inflow boundary fluxes for all these simulation events were obtained through the above-mentioned hydrological analysis. As the flow regime is assumed to be supercritical, no boundary condition is needed at the downstream end.

The initial conditions require the representation of the initial water level over the entire study domain, which in this case was completely dry before the start of every simulation as shown in the Fig. 5. Though it was dry, for the purpose of numerical initiation we have assumed a very diminutive quantity of water being present in the computational domain. For this reason, a water depth of $0.0001 \mathrm{~m}$ is assumed as an initial condition for every simulation. As the information on soil is also an initial condition, based on the field survey report a georeferenced digital soil map of the study area containing information on sediment properties like density and diameter was prepared and imported in SediMorph for using it in the simulations.

Based on stochastic model of the void structure and void sizes as demonstrated by Åberg (1992), the sediment porosity calculations were included in the simulation of sediment erodability. Additionally, as SediMorph requires the information on salinity and water temperature, the same values as observed during the field measurements were utilised on an average basis. In this study for all the simulation events, the bed load sediment transport capacity was calculated using Van Rijn's sediment transport law as it is valid for the simulation of transport of medium sand particles.

Then the erosion and deposition flux of suspended sediments were calculated according to Partheniades (1965) and Krone (1962). For this purpose, the mode of transport for medium sand fractions was defined as bed load and for the fine silt fractions, it was defined as suspension. The critical shear stress and the settling velocity needed for the 


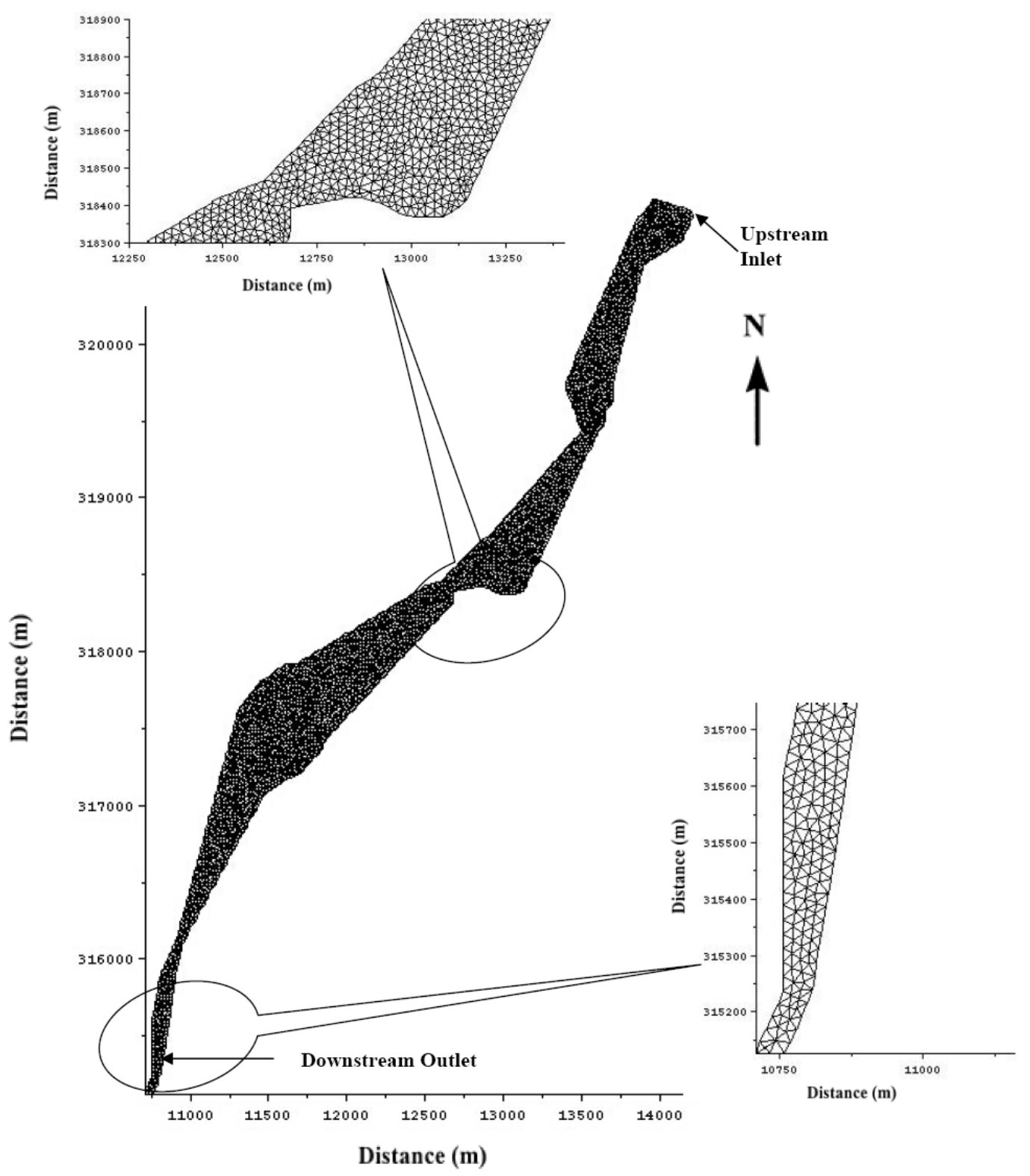

Fig. 4. Finite element mesh of the Pathri Rao River.

Obr. 4. Siet' konečných prvkov rieky Pathri Rao.

initiation of sediment motion and transport of suspended sediments were calculated using Shields criteria and Stokes relations, respectively. The grain size dependent Nikuradse friction coefficient was utilised in the computations for accounting the frictional energy losses. Generally, in the numerical simulations, the computational time step is limited by numerical stability conditions, such as the Courant-Friedrichs-Lewy (CFL) condition. Hence, during the model testing, we tried to use a stable and reliable solution in each case. In the free surface equations, the advection of velocity was solved always using the method of characteristics and the advection of depth was solved using the conservative streamline-upwind Petrov-Galerkin (SUPG) scheme. For stability reasons, the mass matrix is lumped and the time discretization was kept semiimplicit with a Crank-Nicolson factor of 0.6.

\section{Results and discussions}

With the above-mentioned datasets, simulation methodology and modelling criteria, the hydrodynamic and morphodynamic simulations were cou- 


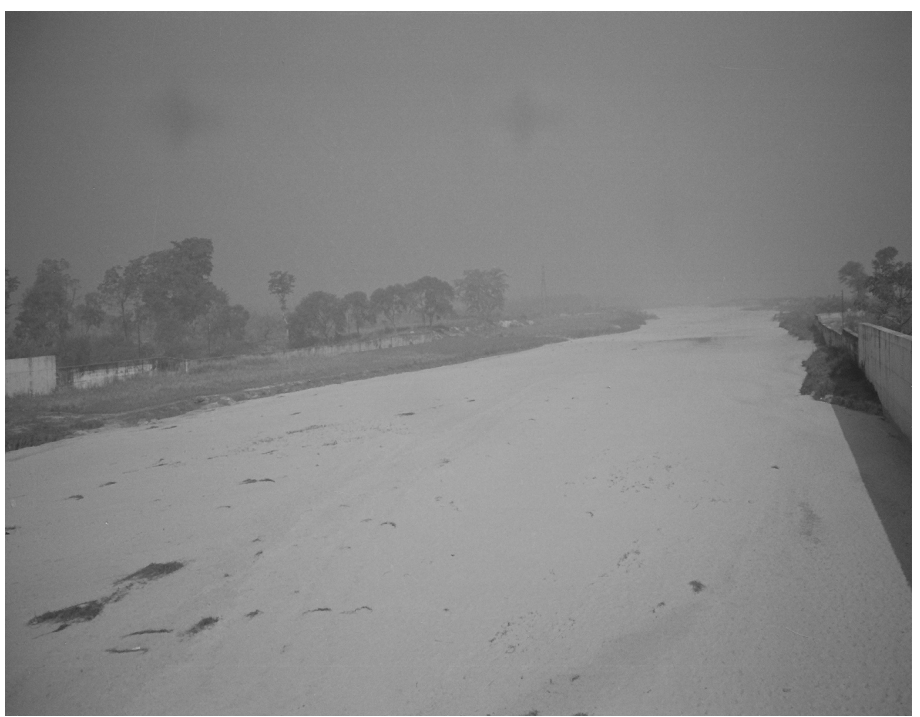

Fig. 5. Initial dry bed conditions of the Pathri Rao River reach before every simulation. (It can be seen that the bed is quite flat over a lateral cross-section.)

Obr. 5. Počiatočné podmienky v koryte rieky Pathri Rao pred každou simuláciou. (Možno vidiet’ že dno v priečnom reze je celkom ploché.)

pled for the runoff events. To visually fit the simulated hydrograph with that of the observed one, the bed roughness coefficient was chosen as the calibration parameter as done in previous studies of Stewart et al. (1999), Horritt, Bates (2002) and been calibrated for two events. The remaining two events that are not subjected to a calibration procedure were used for validation. The calibrated value of Nikuradse constant is 0.025 . The model fit was judged by visual matching of observed and computed hydrographs in terms of magnitude of peak and time to peak of the hydrograph. Results for each of the simulations are graphically expressed in Fig. 6a-d. In general, it appears that the time-topeak, magnitude of peak and the shape of the simulated discharge hydrographs resemble those of the observed data and are in the acceptable limits. As TELEMAC-2D was validated extensively through the studies by Stewart et al. (1999), Horritt, Bates (2002), the detailed evaluation of the simulation results obtained is not reported here. Therefore, only validation for sediment transport and bed morphology modules of SediMorph are covered in this section.

Here the suspended and bed load transport are validated separately. The validation of the former is approached by comparing the depth-averaged suspended transport concentrations against experimental measurements made at the make-shift gauging station. The latter is approached only on qualitative basis. The results obtained for the suspended sedi- ment transport from the SediMorph simulations are presented in Tab. 3. As can be seen from Tab. 3, the computed volume of sediment outflows for each storm event, peak rate of sediment outflows and time to peak of sediment outflows compares reasonably well with the corresponding observed values for the simulated events. Despite neglecting sediment influx from the upstream catchment and the bed load transport rates, results presented in the Tab. 3 indicate that values computed by SediMorph are within the acceptable limits having a maximum error of $\pm 30 \%$.

Non-availability of exclusive bed load measurements compelled us to validate the bed load transport simulations in a qualitative manner. Analysing the simulation results revealed that for all the simulations the bed load transport rates are very low throughout the study area at different time steps. For graphical representation of the above fact, spatially distributed bed load transport rates at different time steps were plotted for all the events. Fig. 7 depicts those plots for the event occurred on August 26, 2006 as an illustration which shows low rates of bed load transports at various locations within the study reach. Moreover, from the simulation it seems that the most of eroded sediment fractions which moves as bed load get deposited within the study reach without reaching the outlet, thus, it may not significantly contribute to the total sediment yield. 
$\mathrm{T}$ a b 1 e 3. Comparison of the simulated sedimentographs (for suspended sediments) with the observations.

$\mathrm{T}$ a b u l' k a 3. Porovnanie simulovaných sedimentografov (pre suspendované sedimenty) s pozorovaniami; 1 - čas udalosti, 2 pozorovaný čas maximálnej rýchlosti suspendovaných sedimentov, 3 - simulovaný čas maximálnej rýchlosti suspendovaných sedimentov, 4 - pozorovaná maximálna rýchlost' suspendovaných sedimentov, 5 (f) simulovaná maximálna rýchlost' suspendovaných sedimentov, 6 - chyba v percentách, 7 - pozorovaný celkový objem sedimentov, 8 - simulovaný celkový objem sedimentov.

\begin{tabular}{|c|c|c|c|c|c|c|c|c|}
\hline $\begin{array}{l}\text { Event } \\
\text { date }^{1)}\end{array}$ & $\begin{array}{l}\text { Observed } \\
\text { time of peak } \\
\text { suspended } \\
\text { sediment } \\
\text { rate }^{2)} \\
{[\mathrm{h}]}\end{array}$ & $\begin{array}{l}\text { Simulated } \\
\text { time of peak } \\
\text { suspended } \\
\text { sediment } \\
\text { rate }^{3)} \\
{[\mathrm{h}]}\end{array}$ & $\begin{array}{l}\text { Observed } \\
\text { volume of } \\
\text { peak sus- } \\
\text { pended } \\
\text { sediment } \\
\text { rate }^{4)}\left[\mathrm{kg} \mathrm{s}^{-1}\right]\end{array}$ & $\begin{array}{l}\text { Simulated vol- } \\
\text { ume of peak } \\
\text { suspended } \\
\text { sediment rate } \\
{\left[\mathrm{kg} \mathrm{s}^{-1}\right]}\end{array}$ & $\begin{array}{l}\text { Percentage } \\
\text { error }^{6)} \\
{[\%]}\end{array}$ & $\begin{array}{l}\text { Observed } \\
\text { total sedi- } \\
\text { ment yield } \\
\text { [tons] }\end{array}$ & $\begin{array}{l}\text { Simulated } \\
\text { suspended } \\
\text { sediment } \\
\text { yield }^{8)} \\
{[\text { tons] }}\end{array}$ & $\begin{array}{l}\text { Percentage } \\
\text { error } \\
{[\%]}\end{array}$ \\
\hline 30.7 .06 & 4.00 & 4.50 & 1.40 & 0.81 & -41.98 & 9.83 & 6.87 & -30.11 \\
\hline 14.8 .06 & 4.00 & 3.75 & 2.28 & 1.52 & -33.55 & 10.65 & 8.44 & -20.75 \\
\hline 26.8 .06 & 4.5 & 4.00 & 1.59 & 1.16 & -26.69 & 10.93 & 8.58 & -21.50 \\
\hline 12.9 .06 & 10.00 & 10.25 & 1.69 & 1.34 & -20.71 & 22.13 & 16.15 & -27.02 \\
\hline
\end{tabular}

For example, Fig. 7 shows very modest bed load transport rates at regions near the outlet for the August 26, 2006 event agreeing with the above said observation. This is valid for all the other simulated events too. Likewise, a closer observation of the illustrative Fig. 7 tells us that only at the region of inflow and in the regions of possible high velocities (curved cross-sections with small width) most of the bed load transport occurs and as a result, it erodes few soils particles in those locations as seen in Fig. 8c. In the other regions, very low bed load transports seem to occur. Due to such low rates of bed load movement over a major portion of the study area, no major change in the bed profile has occurred. It is clearly portrayed in the Fig. 8a-d, which shows the change in bathymetry after every simulation. The simulations clearly revealed that in this study area, the major mode of transport of sediments is in suspension mode and hence bed load transport rates can be neglected in calculating total sediment outflow from the study area. This observation justifies our exclusion of bed loads in calculating the total sediment outflows from the river reach. As there is no presence of coarser particles like gravel or boulders to move as bed load, this fact could be scientifically a valid one too.

\section{Conclusions}

SediMorph a morphodynamic model based on depth-averaged suspended sediment, bed load and sediment continuity equation is presented. It is coupled with TELEMAC-2D for simulating temporal distribution of runoff, bed profile changes and the sediment outflow rate during a few runoff events that occurred in the Pathri Rao River.
In general, the models produced satisfactory predictions for temporal variation of storm runoff, bed profile changes and sediment outflows for the storm events studied. From the simulations, it could be concluded that the bed load transport and bed evolution process are not a major phenomenon in this study area and could be neglected in the simulation of temporal distribution of total sediment transport calculations. From the deeper analysis of the results, we could conclude that the higher percentage of error in predictions against the observations should be due to the non-accountability of the sediment influx from the upstream catchment. This study also demonstrates that the SediMorph coupled with TELEMAC-2D could be used with confidence for practical applications in the Pathri Rao River. However, better results could be achieved by accounting the upstream stream influx in the calculation of sediments transport during the storm events.

Acknowledgements. The first author is grateful to DAAD (Deutscher Akademischer Austauschdienst) for their financial support to carry out this work under Sandwich model fellowship. The authors are grateful to Prof. Dr. U.C. Kothyari and Prof. Dr. S.K. Ghosh, Indian Institute of Technology Roorkee, for providing necessary help in collecting the essential datasets for carryout this modelling work.

\section{REFERENCES}

ÁBERG B.,1992: Void ratio of noncohesive soils and similar materials. J Geotech Eng., 118, 9, 1315-1333.

ENGELUND F., HANSEN E., 1967: A Monograph on Sediment Transport in Alluvial Streams. Copenhagen.

GALLAND J.C., GOUTAL N., HERVOUET J.-M., 1991: TELEMAC - a new numerical-model for solving shallowwater equations. Adv Water Resour, 14, 3, 138-148. 

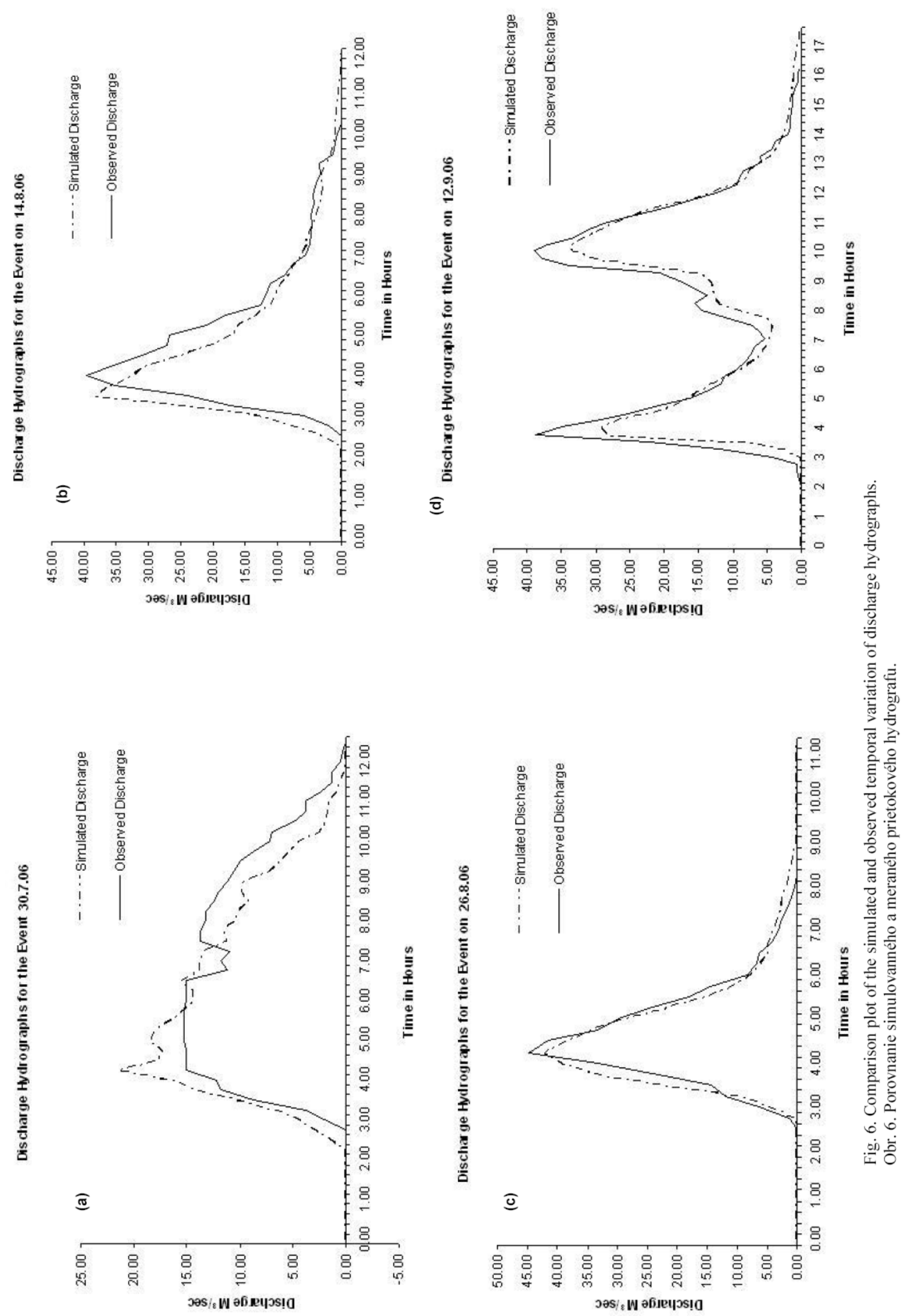


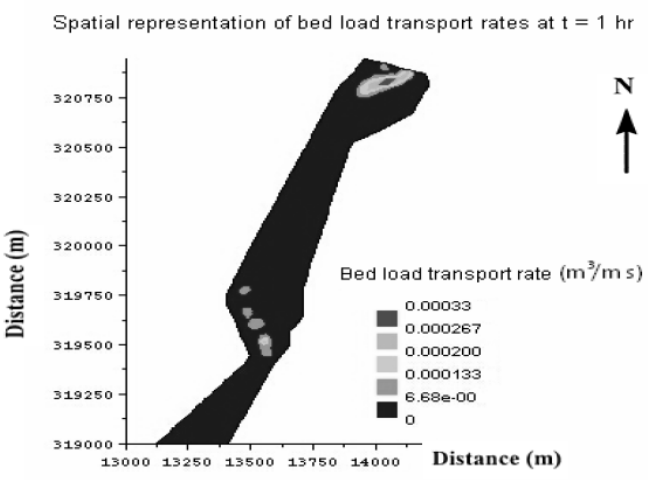

Spatial representation of bed load transport rates at $\mathrm{t}=3 \mathrm{hr}$

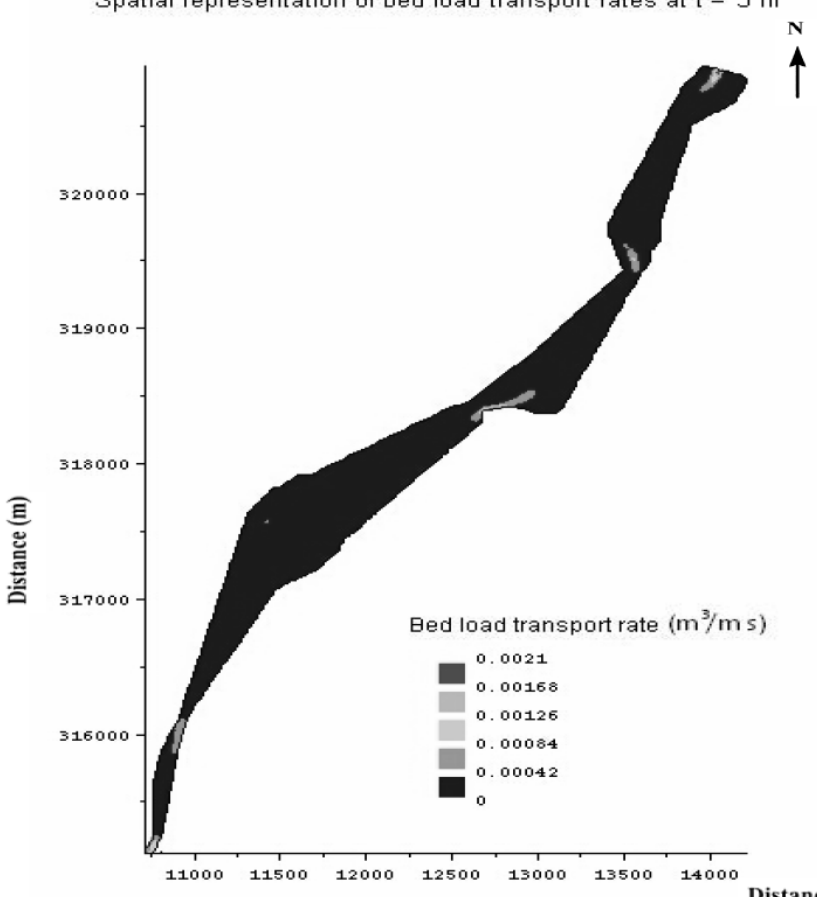

Distance (m)

Spatial representation of bed load transport rates at $\mathrm{t}=6 \mathrm{hr}$

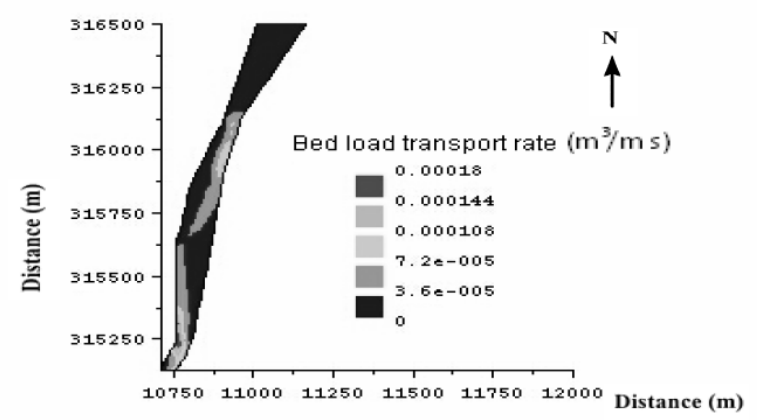

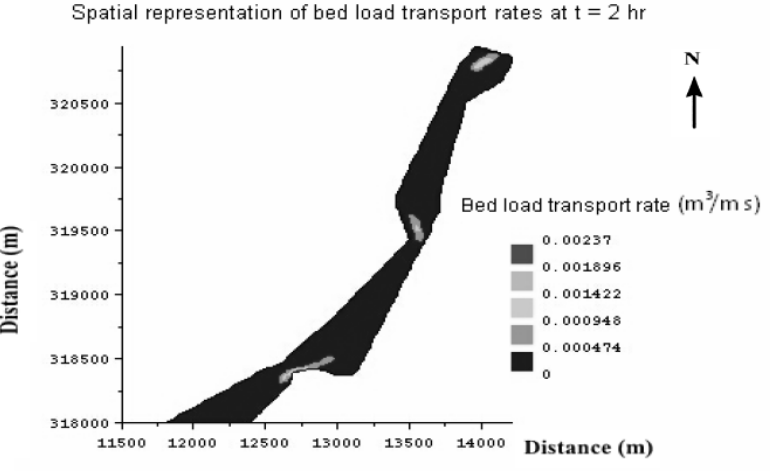

Spatial representation of bed load transport rates at $t=4 \mathrm{hr}$

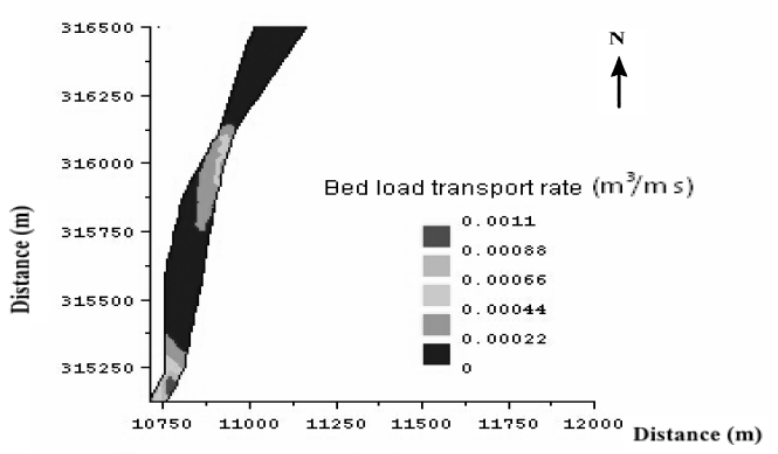

Spatial represenatation of bed load transport rates at $\mathrm{t}=5 \mathrm{hr}$

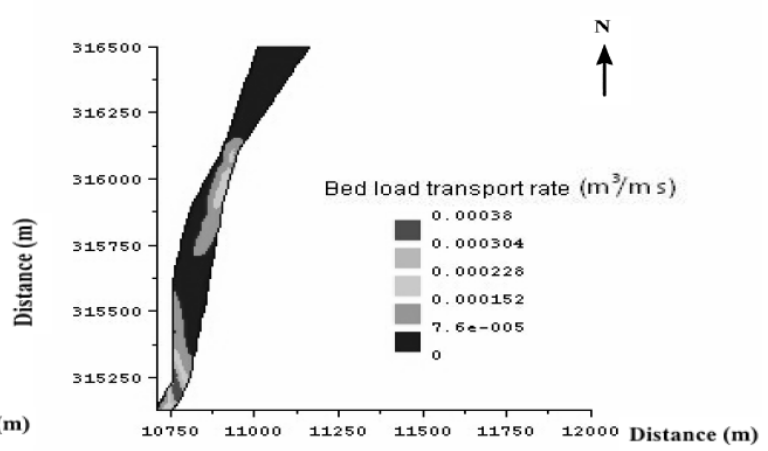

Spatial representation of bed load transport rates at $t=8 \mathrm{hr}$

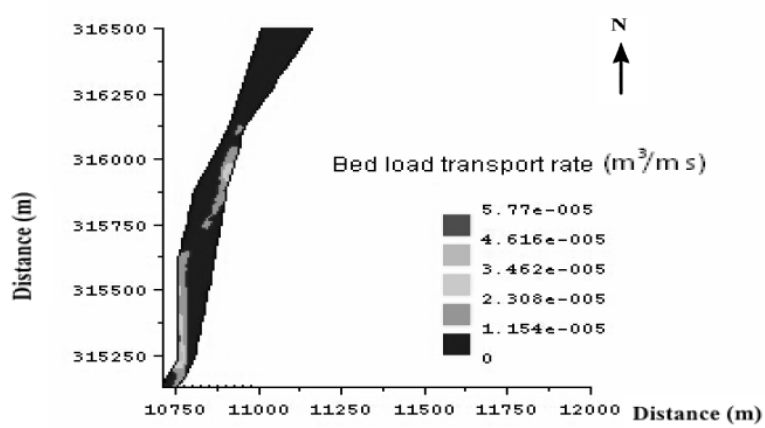

Fig. 7. Spatial representation of bed load transport rates at different time steps during the event August 26, 2006.

Obr. 7. Priestorová reprezentácia rýchlostí transportu dnových sedimentov v rôznych časových krokoch počas zrážky 26. 8. 2006. 


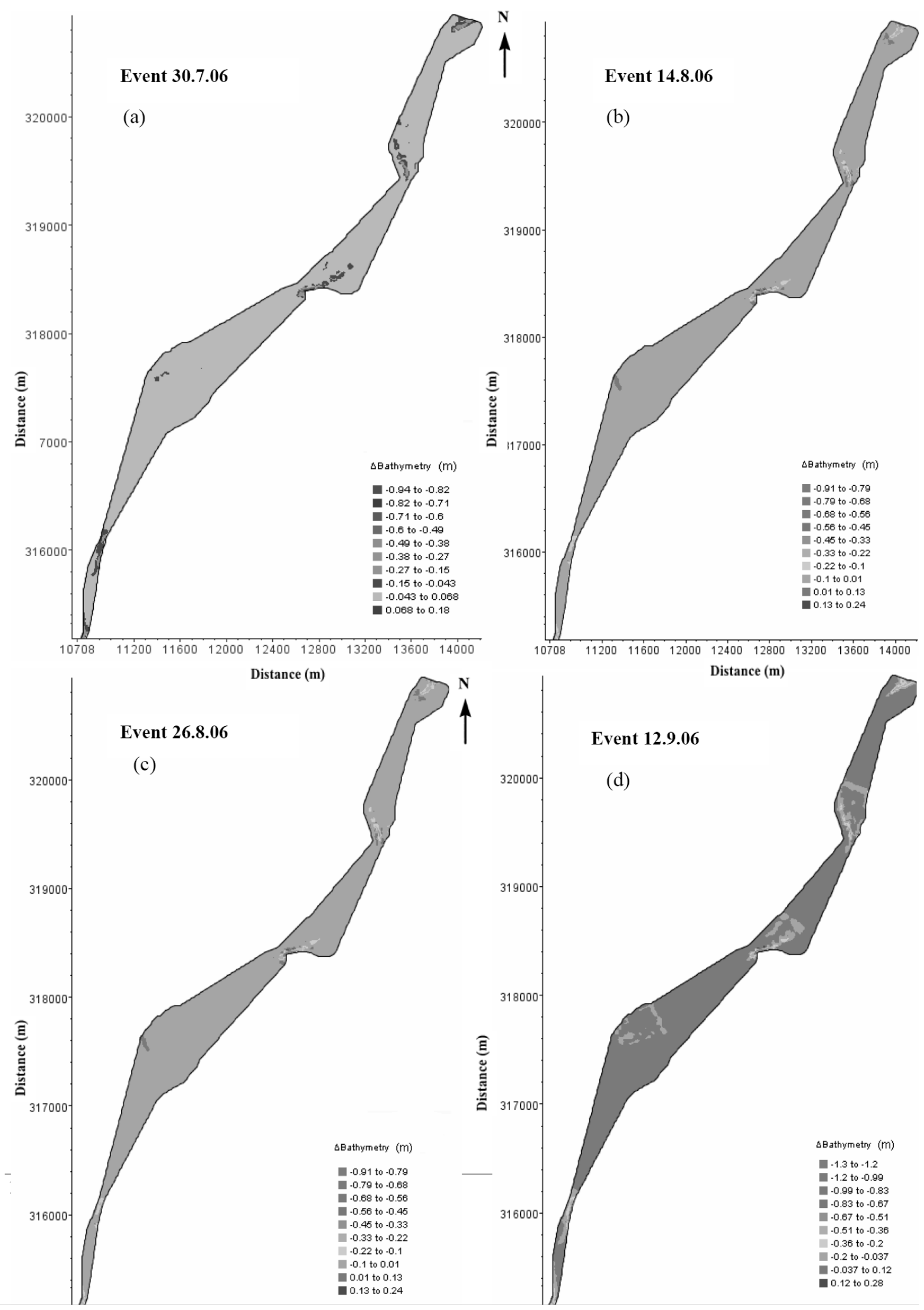

Fig. 8. Spatial representation of the bed evolution changes after each storm event.

Obr. 8. Priestorová reprezentácia zmien v koryte rieky po každej odtokovej epizóde. 
HERVOUET J.M., BATES P., 2000: The TELEMAC modelling system. Hydro Proc., 14, Special Issue.

HORRITT M.S., BATES P.D., 2002: Evaluation of 1D and 2D numerical models for predicting river flood inundation. J. Hydrol., 268, 1-4, 87-99.

KRONE R.B., 1962: Flume studies of the transport of sediment in estuarial processes. Final report Hydraul. Eng. Lab. Sanit. Eng. Lab University of California, Berkeley, 215 p.

MALCHEREK A., PIECHOTTA F., KNOCH D., 2005 : Mathematical Module SediMorph - Validation Document version 1.1. Federal Waterways Engineering and Research Institute (BAW) http://www.baw.de/vip/abteilungen /wbk/Methoden/hnm/sedimorph/vd-sedimorph.pdf.

MEYER-PETER E., MÜLLER R., 1949: Eine Formel zur Berechnung des Gescheibetrides. Schweizerische Bauzeitung, 67, 3, 29-32.

PARTHENIADES E., 1965: Erosion and deposition of cohesive soils. J. Hydraul. Div., ASCE, 91, HY1, 105-138.

PEUCKER T.K., FOWLER R.J., LITTLE J.J., MARK D.M., 1978: The Triangulated Irregular Network. Proceedings, American Society of Photogrammetry: Digital Terrain Models (DTM) Symposium, St. Louis, Missouri, May 9-11, pp. 516-540.

RAMSANKARAN R., KOTHYARI U.C., GHOSH S.K., MALCHEREK A., 2009: GIS based hydrological modelling of extreme events in a forested mountainous catchment. IHP VII, UNESCO Technical Documents in Hydrology, No 84, UNESCO, Paris.

STEWART M.D., BATES P.D., ANDERSON M.G., PRICE D.A., BURT T.P., 1999: Modelling floods in hydrologically complex lowland river reaches. J. Hydrol., 223, 1-2, 85-106 .

VAN RIJN L.C., 1984: Sediment transport. Part III: Bed forms and alluvial roughness. J. Hydraul. Eng., ASCE, 110, 12, 1733-1754.

ZANKE U., 1999: Analytische Lösung für den Geschiebetrieb. Wasser und Boden, 51, 6, 46-52.

Received 13 February 2009 Accepted 14 October 2009

NUMERICKÉ MODELOVANIE HYDRODYNAMICKÝCH JAVOV A TRANSPORTU SEDIMENTOV POČAS PRÍVALOVÝCH ZRÁŽOK V OBČASNÝCH TOKOCH

Raaj Ramsankaran, Christian Maerker, Andreas Malcherek

Príspevok obsahuje morfodynamický model SediMorph, ktorý modeluje priemerné hodnoty suspendovaných sedimentov vo vertikálnom profile a transport dno- vých sedimentov. Je zdvojený s modelom TELEMAC2D, ktorý simuluje časové rozdelenie odtoku, zmeny profilu koryta a prietok sedimentov počas niekol'kých odtokových epizód rieky Pathri Rao.

Modely umožňujú uspokojivé predpovede časových zmien odtoku počas prívalových zrážok, zmeny profilu koryta a odtoku sedimentov $\mathrm{v}$ študovaných epizódach. Zo simulácií vyplýva, že dnový transport a zmeny morfológie toku nie sú v tejto oblasti hlavnými javmi a pri simulácii časového rozdelenia celkového transportu sedimentov môžu byt' zanedbané. Hlbšou analýzou výsledkov možno príst' $\mathrm{k}$ záveru, že vysoký podiel chýb v predpovediach $\mathrm{v}$ porovnaní $\mathrm{s}$ pozorovaniami je dôsledkom zanedbania prítoku sedimentov $\mathrm{z}$ vyššieležiaceho povodia. Táto štúdia tiež demonštruje vhodnost' využitia spojených modelov SediMorph a TELEMAC-2D pre spolahlivé použitie na toku Pathri Rao. Lepšie výsledky však možno dosiahnut' s uvážením vplyvu prítoku sedimentov do toku z povodia, ležiaceho nad ním.

\section{Zoznam symbolov}

$\tau_{\mathrm{c}} \quad-$ Shieldovo kritické tangenciálne napätie [-],

$\theta_{\mathrm{c}} \quad$ - Shieldov parameter $[-]$,

$\bar{\rho}_{\mathrm{s}} \quad-$ priemerná hustota sedimentov $\left[\mathrm{kg} \mathrm{m}^{-3}\right]$,

$\rho \quad$ - hustota vody $\left[\mathrm{kg} \mathrm{m}^{-3}\right]$,

$d_{50}-$ medián priemeru častíc $[\mathrm{m}]$,

$\Phi_{\text {ero }}-$ erózny tok $\left.\left[\mathrm{kg} \mathrm{m}^{-2} \mathrm{~s}^{-1}\right)\right]$,

$M_{\text {res }}$ - rýchlost' erózie $\left.\left[\mathrm{kg} \mathrm{m}^{-2} \mathrm{~s}^{-1}\right)\right]$,

$\tau_{\mathrm{b}} \quad$ tangenciálne napätie na dne $\left[\mathrm{N} \mathrm{m}^{-2}\right]$,

$\tau_{\mathrm{ce}} \quad$ kritické tangenciálne napätie pre eróziu $\left[\mathrm{N} \mathrm{m}^{-2}\right]$,

$\Phi_{\text {dep }}-$ rýchlost' depozície $\left.\left[\mathrm{kg} \mathrm{m}^{-2} \mathrm{~s}^{-1}\right)\right]$,

$W_{\mathrm{c}} \quad$ rýchlost' usadzovania $\left[\mathrm{m} \mathrm{s}^{-1}\right]$,

c - priemerná koncentrácia sedimentov po híbke $\left[\mathrm{kg} \mathrm{m}^{-3}\right]$,

$\tau_{\mathrm{cd}} \quad-$ kritické tangenciálne napätie pre depozíciu $\left[\mathrm{N} \mathrm{m}^{-2}\right]$,

$n$ - pórovitost' vrchnej vrstvy sedimentov [-],

$z_{\mathrm{B}} \quad$ - vertikálna súradnica vrchnej vrstvy sedimentov [m],

$q_{s} \quad$ rýchlost' prenosu sedimentov v koryte toku $\left[\mathrm{m}^{3} \mathrm{~m}^{-1} \mathrm{~s}^{-1}\right]$,

$\rho_{\mathrm{s}} \quad-$ hustota suchých sedimentov $\left[\mathrm{kg} \mathrm{m}^{-3}\right]$,

$\Phi_{\mathrm{S}}$ - rýchlost' prenosu sedimentov medzi vodou a korytom toku $\left.\left[\mathrm{kg} \mathrm{m}^{-2} \mathrm{~s}^{-1}\right)\right]$,

$u, v$ - zložky rýchlostí v smeroch $x$ a $y\left[\mathrm{~m} \mathrm{~s}^{-1}\right]$,

$h$ - hĺbka vodného prúdu [m],

$z_{\mathrm{b}} \quad$ - výška koryta toku [m],

$v_{\mathrm{t}} \quad-$ turbulentná viskozita $\left[\mathrm{m}^{2} \mathrm{~s}^{-1}\right]$,

$S_{x}, S_{y}$ - zdrojový člen (trenie na dne, Coriolisova sila, atd'.) $\left[\mathrm{m} \mathrm{s}^{-2}\right]$,

g - gravitačné zrýchlenie $\left[\mathrm{m} \mathrm{s}^{-2}\right]$,

$t \quad-$ čas [s] 